Nafi'ah

p-ISSN 2621-3184 ; e-ISSN 2621-4032

doi: 10.36387/jifi.v3i2.587

\title{
EFEKTIFITAS KOMBINASI GREEN TEA EXSTRACT DAN SENOBI BREATHING EXERCISE UNTUK MENURUNKAN PREVALENSI LEMAK TUBUH REMAJA OVERWEIGHT PADA KONDISI AKUT
}

\author{
Nafi'ah $^{1 *}$, Mu'jizatillah $^{1}$, Jhudi Bonosari Soediono ${ }^{2}$ \\ ${ }^{1}$ Program Studi DIII Fisioterapi Politeknik Unggulan Kalimantan \\ ${ }^{2}$ Program Studi DIII Farmasi politeknik Unggulan Kalimantan \\ *: nafiah@polanka.ac.id
}

\begin{abstract}
ABSTRAK
Dalam dekade terakhir terjadi peningkatan prevalensi remaja overweight. Berdasarkan hal tersebut strategi dan produk telah dievaluasi dalam upaya mencegah dan mengobati overweight menggunakan Green Tea Extract (GTE) dan Senobi Breathing Exercise (SBE). Namun, hingga saat ini belum diketahui efek pemberian GTE dan SBE terhadap penurunan persentase lemak tubuh remaja pada kondisi akut jika dikombinasikan. Metode yang digunakan adalah quasi experimental with control group design. Penelitian dilakukan di laboratorium gymnasium Politeknik Unggulan Kalimantan pada Maret 2020. Sampel yang digunakan berusia 18-21 tahun dengan BMI 25-29,9. Penentuan jumlah sampel menggunakan rumus Federer: $(\mathrm{t}-1)(\mathrm{n}-1) \geq 15$ didapatkan 4 kelompok perlakuan dengan jumlah sampel setiap kelompok 10 orang yang dibagi secara acak menjadi: (a) kelompok overweight yang diberi GTE; (b) kelompok overweight yang diberi SBE; (c) kelompok overweight yang diberi GTE dan SBE; (d) kelompok overweight yang tidak diberi pelakuan. Pengukuran persentase lemak tubuh pada kondisi akut dilakukan sesaat setelah intervensi menggunakan Body Fat Monitor Scale GEA Medical EF 981. Setelah dilakukan uji statistik krusskall wallis didapatkan hasil $\mathrm{P}>0,05$ yang menunjukkan tidak ditemukan adanya efek signifikan GTE dan SBE untuk menurunkan prevalensi lemak tubuh remaja overweight pada kondisi akut. Penelitian lebih lanjut diperlukan untuk mengetahui protokol yang tepat
\end{abstract}

Kata Kunci: Overweight, Remaja, Senobi Breathing Exercise, Green Tea Extract,

\section{ABSTRACT}

In last decade there has been an increase prevalence of overweight adolescents. Various strategies and products have been evaluated in effort to prevent and treat overweight using Green Tea Extract (GTE) and Senobi Breathing Exercise (SBE). However, the effect of GTE and SBE on decreasing adolescent body fat percentage in acute conditions when combined are unknown. The method used quasi experimental with control group design. The research conducted in Gymnasium laboratory of the Politeknik Unggulan Kalimantan in March 2020. The samples used were aged 18-21 years with BMI 25-29.9. Determination of samples using Federer's formula: (t-1) (n-1) $\geq 15$ obtained 4 treatment groups with a sample size of each group are 10 people that divided into: (a) overweight GTE; (b) overweight SBE; (c) overweight GTE and SBE; (d) overweight control. Measurement percentage of body fat in acute conditions shortly after treatment 
Jurnal Insan Farmasi Indonesia, 3(2) Desember 2020 (354-360)

Nafi'ah

p-ISSN 2621-3184; e-ISSN 2621-4032

doi: 10.36387/jifi.v3i2.587

utilize Body Fat Monitor Scale GEA Medical EF 981. Statistical Test using Krusskall Wallis, the results obtained were $P>0.05$, which indicates that there was no significant effect of GTE and SBE to reduce prevalence of adolescent body fat in acute conditions. Further research is needed to find out the correct protocol.

keywords: Overweight, Adolescent, Senobi Breathing Exercise, Green Tea Extract

\section{PENDAHULUAN}

Dalam dekade terakhir overweight pada remaja telah menjadi masalah kesehatan di negara-negara maju dan berkembang, termasuk Indonesia. Berdasarkan data World Health Organization (WHO) Diketahui prevalensi obesitas di seluruh dunia hampir tiga kali lipat antara tahun 1975 hingga 2016. Pada tahun 2016 didapatkan 18\% remaja mengalami kelebihan berat badan.(1) Di Indonesia, Kementerian Kesehatan RI mengungkap prevalensi overweight hingga obesitas secara nasional terus meningkat, dan Indonesia menempati peringkat ke-10 dunia. Berdasarkan data Riset Kesehatan Dasar (Riskesdas) kejadian overweight pada remaja 16-18 tahun mengalami peningkatan dimulai dari 1,4 persen pada tahun 2010 menjadi 7,3 persen pada tahun 2013.(2) Tingginya prevalensi yang terjadi diakibatkan oleh berbagai macam faktor seperti perubahan pola makan serta sediktnya akivitas fisik yang dilakukan menyebabkan ketidakseimbangan antara asupan dan pengeluaran kalori sehingga terjadi kelebihan energi yang selanjutnya disimpan sebagai trigliserida di jaringan adiposa yang akan menimbulkan inflamasi pada jaringan adipose sehingga terjadi overweight.(3)

Overweight merupakan faktor dari berbagai masalah kesehatan seperti kejadian diabetes mellitus tipe 2, penyakit jantung koroner, stroke, kanker, asma, penyakit paru obstruktif kronis dan sebagainya. (4) Sehingga overweight harus diberikan penanganan yang tepat. Berdasarkan hal tersebut, dalam decade terakhir berbagai strategi dan produk telah dievaluasi dalam upaya untuk mencegah dan mengobati overweight baik secara farmakologis maupun non farmakologis. Akan tetapi keterbatasan biaya serta waktu seringkali menjadi hambatan, oleh karena itu pada penelitian ini kami 
Jurnal Insan Farmasi Indonesia, 3(2) Desember 2020 (354-360)

Nafi'ah

p-ISSN 2621-3184; e-ISSN 2621-4032

doi: $10.36387 /$ jifi.v3i2.587

mengusulkan penanganan secara presentasi lemak tubuh $(5,8)$. farmakologis penggunaan produk Berdasarkan hal tersebut, penanganan Green Tea Exstract (GTE) yang dapat secara farmakologis dan non dengan mudah didapatkan di alam farmakologis ini jika dikombinasikan serta secara non farmakologis kemungkinan besar akan memberikan menggunakan Senobi Breathing efek lebih cepat terhadap penurunan Exercise ( $S B E$ ) yang dapat dilakukan persentase lemak tubuh remaja. oleh populasi yang merasa tidak punya Namun, hingga saat ini belum banyak waktu untuk melakukan diketahui efek pemberian GTE dan exercise. $(5,6)$

GTE adalah salah satu dari produk polyphenol alami yang dapat dengan mudah didapatkan di alam khususnya wilayah Indonesia. Polyphenol telah terbukti menjadi regulator termogenik yang tentunya sangat baik untuk menurunkan presentase lemak tubuh melalui proses thermogenesis pada jaringan adiposa coklat/BAT yang berperan penting dalam pengeluaran energi dalam bentuk panas melalui oksidasi asam lemak yang diperankan oleh Uncoupling Protein 1 (UCP-1).(7-9) Seperti halnya GTE, SBE juga menurunkan prevalensi lemak tubuh melalui proses thermogenesis yang akan memberikan efek menguntungkan terhadap penurunan $S B E$ terhadap penurunan persentase lemak tubuh pada remaja jika dikombinasikan. Oleh karena itu penulis tertarik untuk mengetahui efektifitas dari kombinasi GTE dan $S B E$ terhadap penurunan prevalensi lemak tubuh remaja penderita overweight pada kondisi akut.

\section{METODE PENELITIAN}

Desain penelitian ini menggunakan quasi experimental with control group design yang dilakukan di Laboratorium Gymnasium Politeknik Unggulan Kalimantan pada bulan Maret 2020. Sampel yang digunakan berusia 18-21 tahun dengan Body Mass Index (BMI) 25-29,9 kategori overweight.

Penelitian ini dibagi menjadi 4 kelompok yang terdiri dari: (a) 
Jurnal Insan Farmasi Indonesia, 3(2) Desember 2020 (354-360)

Nafi'ah

p-ISSN 2621-3184 ; e-ISSN 2621-4032

doi: $10.36387 /$ jifi.v3i2.587

kelompok overweight yang diberikan intervensi GTE (OwGTE); (b) kelompok overweight yang diberi $S B E$ (OwSBE); (c) kelompok overweight yang diberikan intervensi GTE dan $S B E(O w G S)$; (d) kelompok kontrol (OwK). Penentuan jumlah sampel menggunakan rumus Federer: $(\mathrm{t}-1)(\mathrm{n}-$ 1) $\geq 15$. Berdasarkan perhitungan menggunakan rumus tersebut maka diperoleh jumlah sampel minimal untuk 4 perlakuan adalah 5 orang. Adapun pada penelitian ini, peneliti menggunakan 10 sampel pada masingmasing perlakuan. Selanjutnya, sampel diberikan intervensi berupa: (a) konsumsi GTE sebanyak $250 \mathrm{mg}$ untuk kelompok OwGTE dan OwGS ; (b) $S B E$ selama 2 menit untuk kelompok OwSBE dan OwGS. Kemudian, untuk mengukur efek akut persentase lemak tubuh dilakukan sesaat setelah intervensi menggunakan Body Fat Monitor Scale GEA Medical EF 981.

Selanjutnya analisis statistic dilakukan menggunakan uji one way anova jika data berdistribusi normal dan homogen. Namun, jika data berdistribusi tidak normal dan tidak homogen, maka analisis menggunakan uji kruskall wallis. Pengolahan data dilakukan menggunakan program statistik komputer SPSS 20.

\section{PEMBAHASAN}

Berdasarkan hasil uji statistik menggunakan kruskall wallis dikarenakan data berdistribusi normal namun tidak homogen didapatkan nilai $\mathrm{P}>0,05$ (grafik 1). Hal ini menunjukkan bahwa tidak ditemukan adanya perbedaan rerata pada masingmasing kelompok perlakuan yang mengindikasikan bahwa tidak adanya pengaruh pemberian intervensi green tea exstract dan senobi breathing exercise terhadap prevalensi lemak tubuh remaja pada kondisi akut.

Tidak adanya signifikansi statistik khusunya pada $S B E$ yang merupakan salah satu bentuk exercise bersesuaian dengan studi literatur yang menunjukkan tidak ditemukan hasil signifikan dari latihan akut terhadap penurunan prevalensi lemak tubuh, akan tetapi penurunan prelevalensi lemak tubuh terjadi pada latihan yang bersifat kronik.(10) 
Jurnal Insan Farmasi Indonesia, 3(2) Desember 2020 (354-360)

Nafi'ah

p-ISSN 2621-3184 ; e-ISSN 2621-4032

doi: $10.36387 /$ jifi.v3i2.587

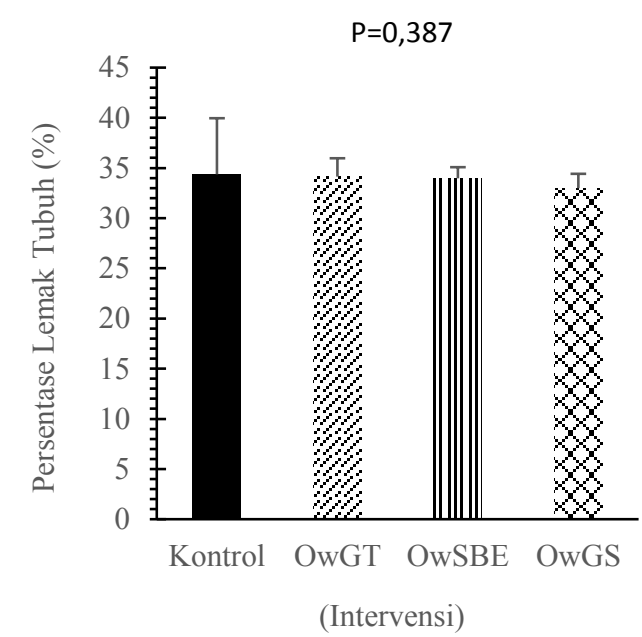

Dulloo dkk, yaitu orang pertama yang menyelidiki tentang GTE, memaparkan bahwa GTE mampu meningkatkan oksidasi asam lemak pada kondisi akut dengan konsumsi 270mg/hari (11). Selain itu penelitian yang dilakukan oleh Rumpler et al juga menunjukkan hal yang sama. Akan tetapi ketika sampel uji diberikan dosis yang lebih kecil, maka

Gambar 1. Rerata Persentase Lemak Tubuh (Mean \pm SD). Tidak Terdapat perbedaan Signifikan $\mathrm{P}>0,05$.

Selain itu, studi lainnya mengkonfirmasi bahwa tidak terdapat efek terhadap intervensi latihan fisik pada kondisi akut. Meskipun Sesi latihan tunggal secara konsisten telah terbukti menstimulasi peningkatan berbagai hormon yang berhubungan dengan penurunan berat badan, namun fluktuasi hormonal hanya terjadi sesaat dan kembali ke nilai kontrol istirahat dalam beberapa saat setelah melakukan latihan.

Kemudian tidak ditemukannya signifikansi uji statistik pada kelompok yang diberikan intervensi GTE memiliki hasil yang berbeda dengan penelitian yang dilakukan oleh

tidak terjadi oksidasi asam lemak pada kondisi akut (12). Berbagai penelitian telah mendukung peningkatan oksidasi lemak sebagai respons terhadap asupan GTE jangka pendek. Namun, tidak semua penelitian menunjukkan peningkatan metabolisme lemak. Tidak ditemukannya penguruh GTE terhadap penurunan prevalensi lemak tubuh yang terjadi pada penelitian ini kemungkinan disebabkan adanya perbedaan dosis yang diberikan. Oleh karena itu, penelitian lebih lanjut diperlukan untuk menjelaskan protokol yang lebih efektif untuk meningkatkan oksidasi lemak sehingga mampu menurunkan prevalensi lemak tubuh. 
Jurnal Insan Farmasi Indonesia, 3(2) Desember 2020 (354-360)

Nafi'ah

p-ISSN 2621-3184 ; e-ISSN 2621-4032

doi: $10.36387 /$ jifi.v3i2.587

Adapun pada kelompok pada kondisi akut.

kombinasi GTE dan $S B E$ meskipun pada uji statistik tidak ditemukan signifikansi, namun kelompok yang diberikan intervensi berupa GTE dan $S B E$ memiliki nilai rerata prevalensi lemak tubuh terendah antar masingmasing kelompok. Hal ini bersesuaian dengan studi yang mempelajari efek akut GTE terhadap oksidasi lemak selama latihan menunjukkan kelompok yang diberikan latihan fisik pada saat konsumsi GTE mengalami laju oksidasi asam lemak yang lebih tinggi. Namun, pada kondisi akut tingkat oksidasi lemak lebih rendah, sehingga sulit untuk mendeteksi terjadinya perubahan prevalensi lemak tubuh $(13,14)$. Penelitian lebih lanjut perlu dilakukan untuk mengetahui protokol intervensi GTE dan $S B E$ dalam menurunkan prevalensi lemak tubuh, khususnya pada remaja.

\section{KESIMPULAN}

Tidak ditemukan pengaruh intervensi Green Tea Extract dan Senobi Breathing Exercise untuk menurunkan perevalensi lemak tubuh remaja yang mengalami overweight

\section{UCAPAN TERIMA KASIH}

Penulis mengucapkan terimakasih kepada instansi Politeknik Unggulan Kalimantan, Yayasan Pucuk Merah, dan Dinas Pendidikan dan Teknogi Perguruan Tinggi (DIKTI) yang telah memfasilitasi dan mendanai penelitian ini.

\section{DAFTAR PUSTAKA}

1. World Health Organization. Obesity and overweight [Internet]. 2018. Available from:

https://www.who.int/newsroom/fact-sheets/detail/obesityand-overweight

2. Kesehatan $\mathrm{K}$, Indonesia $\mathrm{R}$, Ibu K, Anak K, Menular P, Tidak P, et al. Potret sehat indonesia dari riskesdas 2018. Ilmu Kesehat. 2019;(Riskesdas 2013):201820.

3. Blüher M. Obesity: global epidemiology and pathogenesis. Nat Rev Endocrinol. 2019;15(5):28898.

4. Nyberg ST, Batty GD, Pentti J, Virtanen M, Alfredsson L, Fransson EI, et al. Obesity and loss of disease-free years owing to major non-communicable diseases: a multicohort study. 
Jurnal Insan Farmasi Indonesia, 3(2) Desember 2020 (354-360)

Nafi'ah

p-ISSN 2621-3184 ; e-ISSN 2621-4032

doi: 10.36387/jifi.v3i2.587

Lancet Public Heal. 2018;3(10):e490-7.

Changes in Overweight and Obese Individuals: A Review of Recent Evidence. 2014;2014.

5. Sato K, Kawamura T, Yamagiwa S. The "Senobi" breathing exercise ameliorates depression in obese women through up-regulation of sympathetic nerve activity and hormone secretion. Biomed Res. 2011;32(2):175-80.

6. Wang S, Moustaid-Moussa N, Chen L, Mo H, Shastri A, Su R, et al. Novel insights of dietary polyphenols and obesity. J Nutr Biochem. 2014;25(1):1-18.

7. Lee M-S, Shin Y, Jung S, Kim Y. Effects of epigallocatechin3 -gallate on thermogenesis and mitochondrial biogenesis in brown adipose tissues of dietinduced obese mice. Food Nutr Res [Internet]. 2017;61(1):1325307. Available

8. Crichton PG, Lee Y, Kunji ERS. The molecular features of uncoupling protein 1 support a conventional mitochondrial carrier-like mechanism. Biochimie. 2017 Mar;134:3550.

9. Diepvens K, Westerterp KR, Westerterp-Plantenga MS. Obesity and thermogenesis related to the consumption of caffeine, ephedrine, capsaicin, and green tea. Am J Physiol Regul Integr Comp Physiol. 2007;292(1).

10. Dinas PC, Markati AS, Carrillo AE. Exercise-Induced Biological and Psychological

11. Dulloo AG, Duret C, Rohrer D, Girardier L, Mensi N, Fathi M, et al. Efficacy of a green tea extract rich in catechin polyphenols and caffeine in increasing 24-h energy expenditure and fat oxidation. 1999;1040-5.

12. Rumpler W, Seale J, Clevidence B, Judd J, Wiley E, Yamamoto S, et al. Human Nutrition and Metabolism Oolong Tea Increases Metabolic Rate and Fat Oxidation in Men. 2018;(August 2001):2848-52.

13. Hodgson A, Randell R, Jeukendrup A. The Effect of Green Tea Extract on Fat Oxidation at Rest and during Exercise : The Effect of Green Tea Extract on Fat Oxidation at Rest and during Exercise : Evidence of Ef fi cacy and Proposed Mechanisms 1. 2013;(February 2017).

14. Sato K, Kawamura T, Yamagiwa S. The "Senobi" breathing exercise is recommended as first line treatment for obesity. Biomed Res. 2010;31(4):259-62. 